\title{
POSITIVE INTERACTION OF ETHANOL WITH MALIC ACID IN POSTHARVEST PHYSIOLOGY OF CUT SPRAY CARNATION 'WHITE NATILA'
}

\author{
Fatemeh BEGRI ${ }^{1}$, Ebrahim HADAVI ${ }^{1 *}$, Amrollah NABIGOL ${ }^{2}$ \\ ${ }^{1}$ Horticulture Department, Karaj Branch, Islamic Azad University, Karaj, Iran \\ ${ }^{2}$ Horticulture Department, Abhar Branch, Islamic Azad University, Abhar, Iran
}

Received: September 12, 2014; Accepted: November 20, 2014

\begin{abstract}
In this study, succinic acid (0,1 and $2 \mathrm{mM})$, malic acid $(0,1$ and $2 \mathrm{mM})$, ethanol $(0,2$ and $4 \% \mathrm{v} / \mathrm{v})$, and their mixtures were applied as preservative solutions for cut flowers of spread carnation cv. 'White Natila' and their effect on the longevity, the amount of absorbed solution, malondialdehyde and chlorophyll content, cell membrane stability, fresh, and dry weight and on a visual quality was determined. A similarity in the effect of malic acid and succinic acid on dry weight and fresh weight loss were found. Ethanol positively affected most of the studied traits, including the vase life and fresh weight loss. The preservative solution containing $1 \mathrm{mM}$ of malic acid and $4 \%$ ethanol resulted in the longest average vase life -11.1 days compared to 8.9 days in the control. Malic acid showed a significant positive synergism with ethanol that makes it reasonable to combine them in preservative solutions intended to extend the vase life of cut spray carnation.
\end{abstract}

Key words: preservative solution, vase life, visual appearance quality

\section{INTRODUCTION}

To the genus Dianthus belong over 300 species, of which several are grown as ornamental garden plants, cut flowers and potted flowering plants (Brickell 2010). Total world trade of carnation cut flowers reached 527 million USD in 2011 ranked second after rose with 2858 million USD and before orchids and chrysanthemums (UNComtrade 2011). However, limited vase life, as defined by premature senescence of floral organs, creates a significant burden for international trade and marketability of cut carnations.

The vase life of carnation flowers is limited, i.a. by a lack of carbohydrates available for cellular metabolism, which leads to the death of the flower due to starvation. The strong sink activity of the developing ovary competes for the respirable carbohydrates, which otherwise remain available to the petals for metabolism, and this reduces the marketable life of flowers (Podd et al. 2002).
Ethylene is a gaseous plant hormone synthesized by plants via an enzyme catalyzed pathway that binds to specific protein receptors to initiate signal transduction and the typical ethylene responses (Bleecker \& Kende 2000). Exposure to ethylene accelerates flower senescence in cut carnations (Nichols 1968). Treatment of flower stems with silver thiosulphate (STS) solution, an ethylene binding inhibitor, is an effective postharvest treatment for carnation cut flowers (Reid et al. 1983). However, silver is a heavy metal, which can persist in the soil and groundwater for long periods, thus it is considered as an environmental pollutant (Mayers et al. 1997; Rao \& Shantaram 2003). As a consequence, the use of STS is questioned in the main cut flower importing countries including USA and Netherlands (Kosugi et al. 1997; Terék et al. 2009; Zeng et al. 2011), so finding alternative environment friendly methods to prolong the vase life of cut carnations seems necessary. Another point to consider is that spray carnations do not always respond well to 
STS because of differences in flower maturity (Reid 2004).

Exogenous application of ethanol delays the senescence of tomato fruits (Kelly \& Saltveit Jr 1988; Saltveit 1989), oat leaves (Satler \& Thimann 1980) and broccoli florets (Suzuki et al. 2004). Heins and Blakely (1980) applied methanol, ethanol, propanol, tert-butanol and n-butanol to the preservative solution of cut carnations. They reported that the inclusion of $2 \%$ methanol inhibited climacteric ethylene $\left(\mathrm{C}_{2} \mathrm{H}_{4}\right)$ biosynthesis and reduced the respiration rate by $60 \%$ during a 7 -day evaluation period. Wu et al. (1992) found that $8 \%$ ethanol extended the vase life of 'White Sim' carnations more effectively than $2 \%$ and $4 \%$ concentrations. They indicated that in addition to suppression of ethylene biosynthesis, as reported by Heins and Blakely (1980), ethanol treatment could inhibit ethylene action in some other way than by competing with ethylene for its binding site.

Podd and Van Staden (1998, 1999a, b, 2002) conducted a series of studies with ethanol and acetaldehyde, focused mainly on cut carnation flowers. They confirmed that adding 1 or $3 \%$ ethanol to vase solution inhibited ethylene production in cut carnations cv. 'White Sim'. In another study they applied acetaldehyde separately and an alcohol dehydrogenase inhibitor (4-merhyl pyrazole), which inhibited conversion of ethanol to acetaldehyde in plant tissue. They reported that the acetaldehyde produced by ethanol was the agent that triggered ethylene inhibition response (Podd \& Van Staden 1999a). The authors concluded that inhibiting the action of ACC synthase by ethanol was responsible for decreased ethylene formation. Either 3\% ethanol or 2\% acetaldehyde was shown to completely disrupt the process of development and chlorophyll buildup in ovary. This presumably ensured more carbohydrates that were available for petal metabolism leading to an increase in vase life (Podd \& Van Staden 2002).

Pun et al. (1999) used 1, 2, 4, 6 and $8 \%$ ethanol for preservation of five carnations cultivars and found a difference in response of cultivars to ethylene and thus applied ethanol. They assumed that it depends on differences in levels of ethylene production and carbohydrate reserves. To under- stand how ethanol inhibits ethylene production, exogenous ACC at $1 \mathrm{mM}$ was applied to carnation flowers after treatment with $4 \%$ ethanol or $0.05 \%$ acetaldehyde (Pun et al. (2001a). Contrary to earlier conclusion by Heins and Blakely (1980), ethanol and ACC combination reduced the vase life significantly, in a synergistic manner. The authors suggested that the inhibitory effect of ethanol on the biosynthesis of ethylene must occur before formation of ACC (Pun et al. 2001a). The increase in longevity due to application of low levels (0.05 to $0.3 \%)$ of acetaldehyde was reported to be inconsistent among cultivars and was related to a delay in climacteric ethylene production. The authors observed that in 'Yellow Candy', a high-ethylene producer, ethanol is beneficial in increasing vase life but acetaldehyde is not. In contrast, 'Sandrosa' is a naturally low-ethylene producer and a long-lived cultivar, which is not benefited by ethanol but is by acetaldehyde at low concentrations (Pun et al. 2001b).

Kazemi et al. (2010) demonstrated that $1.1 \mathrm{mM}$ malic acid reduced ACC oxidase activity by $39 \%$ and bacterial populations of vase solution by $57 \%$, while increased the relative solution uptake by $33 \%$ and vase life by $30 \%$ in cut carnations. Kazemi et al. (2012) obtained promising results for the vase life longevity by application of malic acid. Succinic acid is reported to cause an increase in the activity of antioxidant enzymes, such as superoxide dismutase, catalase, and soluble peroxidase, and improve the heat resistance of wheat coleoptiles (Kolupaev et al. 2012). This is similar to reports on malic acid (Kazemi et al. 2010, 2012; Zamani et al. 2011). Succinic acid is a precursor to malic acid as an intermediate compound in the tricarboxilic acid cycle. Thus we can expect to see similar results by both compounds if their mode of action was somehow related to their role in Krebs cycle (Darandeh \& Hadavi 2012).

To test this hypothesis we used succinic acid together with malic acid, which could help to compare their effect and get closer to the mechanism of action of malic acid in postharvest vase life of cut carnations. As ethanol was considered beneficial for lengthening of the vase life of carnations, in our experiment, we applied it in combination with malic 
acid and succinic acid to check for any possible positive interactions among them, which could lead to more effective combination in terms of vase life prolongation.

\section{MATERIALS AND METHODS}

\section{Plant material and treatments}

The study was conducted during September 2011. The spray carnations (Dianthus caryophyllus 'White Natila') were grown in a commercial greenhouse at conventional growing conditions. Care was taken to harvest only fully open flowers with uniform appearance. Cut flowers were transferred in water to the laboratory at the agriculture faculty of Islamic Azad University, Karaj Branch. The branches were cut obliquely to a height of $40 \mathrm{~cm}$ and weighed immediately. Cut stems were uniformly distributed among replications to minimize the related variation effect on the experimental results. Three cut flowers were each placed in a bottle containing $500 \mathrm{ml}$ of preservative solutions. During the test, the evaluation room was operated at $19 \pm 2{ }^{\circ} \mathrm{C}$ with $60 \pm 10 \%$ relative humidity and a light cycle of 12 hours light and 12 hours dark. The experiment was conducted in a completely randomized factorial design. The experiment was replicated three times from the same harvest and in each replication, 9 bottles were used with three cut flowers in each, which comprised of 27 cut flowers, making up a total of 81 cut flowers. Malic acid was applied at three concentrations $(0,1$ and $2 \mathrm{mM})$, which was decided based on previous reports (Darandeh \& Hadavi 2012; Kazemi et al. 2010, 2012; Sabzi et al. 2012; Zamani et al. 2011). Succinic acid was applied at the same concentrations as malic acid. Concentrations of ethanol (0, 2 and 4\% v/v) were chosen based on previously obtained results (Podd \& Van Staden 2002; Pun et al. 1999). All the above chemicals were applied at preservative solutions. Except for the vase life, all the measurements in the experiment were done on $7^{\text {th }}$ day coinciding with first signs of flower deterioration in the experiment. All the applied reagents were of analytical grade.

\section{Measurements}

Dry weight. When all the flowers were wilted, they were dried in a ventilated oven in $70{ }^{\circ} \mathrm{C}$ until a con- stant weight and subsequently weighed by a 3-decimal place digital scale.

Chlorophyll Content. Leaf samples ( $0.5 \mathrm{~g})$ were collected from each treatment replicate consisted of three flowers. This was mixed with $0.5 \mathrm{~g}$ of calcium carbonate and $5 \mathrm{~mL}$ of $80 \%$ acetone and ground with pestle and mortar. The mixture was poured into a test tube and centrifuged for 10 minutes at 2800$3000 \mathrm{rpm}$. Then $0.5 \mathrm{ml}$ of the supernatant was mixed with $4.5 \mathrm{ml}$ of acetone and then the absorbance was read in spectrophotometer at 645 and $663 \mathrm{~nm}$. The chlorophyll content was calculated by following formulas as described by Arnon (1949): Total chlorophyll $=\left(0.0202 \times \mathrm{A}_{645}\right)+\left(0.00802 \times \mathrm{A}_{663}\right)$, chlorophyll $\mathrm{a}=\left(0.0127 \times \mathrm{A}_{663}\right)-\left(0.00269 \times \mathrm{A}_{645}\right)$, and chlorophyll $b=\left(0.0229 \times A_{645}\right)-\left(0.00468 \times A_{663}\right)$.

Relative solution uptake by the flowers. Each vessel, including preservative solution and cut flowers, was weighed on a daily basis. Three vessels were filled with plain distilled water and then weighed and used as reference for calculating the net amount of daily-evaporated water from each vessel. This mean value was subtracted daily from amount of preservative solution weight decrease in flower containing vessels to reach out the net daily-absorbed solution by cut flowers. The solution uptake was expressed as relative solution uptake $\left(\mathrm{g} \cdot \mathrm{g}^{-1}\right.$ initial fresh weight $\cdot$ day $^{-1}$ )

Fresh Weight. For this measurement, fresh flowers were weighed by a 3-decimal place digital scale before putting them in solution and on the final day of vase-life they were weighed again and the fresh weight loss was calculated.

Permeability of cell membranes. The electrical conductivity test was used as an indicator of cell membrane permeability. Half a gram of petal samples from each replication were washed several times with distilled water for 2 hours, then placed in $0.71 \%$ mannitol solution and after $24 \mathrm{~h}$ at $25^{\circ} \mathrm{C}$ the electrical conductivity was measured using Conductivity meter (CM-180 ELICO).

Measurement of malondialdehyde (MDA). The method described by Heath \& Packer (1968) with some modifications was used for measuring the malondialdehyde content. Petal samples $(0.5 \mathrm{~g})$ from each replication were isolated on day 7 and ground with $5 \mathrm{ml}$ of $1 \%$ trichloroacetic acid (TCA) 
by pestle and mortar. Then, after a 10 minutes vortexing, the extract was centrifuged for $10 \mathrm{~min}$ at $6000 \mathrm{rpm}$. Five $\mathrm{ml}$ of $10 \%$ TCA solution containing $0.25 \%$ thiobarbituric acid (TBA) was added to $2 \mathrm{ml}$ of the supernatant obtained after centrifugation. An aliquot of $5 \mathrm{ml}$ of the resulting mixture was incubated in water bath $\left(95^{\circ} \mathrm{C}\right)$ for $30 \mathrm{~min}$ and then cooled immediately on ice. The absorbance was measured using a spectrophotometer at 532 and $600 \mathrm{~nm}$.

Quality rating. For quality evaluation of cut flowers, on the seventh day of trial, the flowers were divided into four groups based on visual appearance quality and were scored accordingly from 4 (for the best quality) to 1 (for lowest quality).

Vase Life. Longevity of carnation cut flowers was calculated as time (days) from placing flowers in preservative solution until signs such as petal wilting, discoloration and/or loss was observed in one third of the flowers of each inflorescence. The flowers were checked twice a day for such symptoms.

\section{Statistical analysis of the data}

Analysis of variance was performed using multivariate general linear model (GLM) in SPSS software and Duncan's multiple range test (DMRT) was used for mean separation at 5\% significance level. Path analysis was carried out using AMOS extension of SPSS ver. 16.0 (SPSS Inc., Chicago, USA).

\section{RESULTS AND DISCUSSION}

\section{Dry weight}

Ethanol at the $4 \%$ concentrations caused a significant decrease in dry weight of cut flowers, but only at the $1 \mathrm{mM}$ of malic acid. At the concentration $2 \%$ no significant effect on dry weight was observed. Similarly, the inclusion of malic acid at $2 \mathrm{mM}$ level in vase water caused a significant decrease in dry weight of cut flowers (Table 1, Fig. 1A). Succinic acid levels caused a linear reduction in dry weight as well (Table 1). The respiration peak during senescence is common in many climacteric cut flowers (Halevy \& Mayak 1981), although here we didn't measure the respiration directly but the observed decrease in dry weight could be regarded as a result of an increase in respiration rate and thus as an index of metabolism increase by experimental factors. Dry weight shows a negative and significant correlation with daily relative solution uptake $(-0.229, \mathrm{p}<0.05)$ and a positive with EC value $(0.368, p<0.01)$. The highest dry weight was recorded in the control treatment (Fig. 1A). While it is well documented that an increase in the dry weight of ovary is associated with senescence in carnations (Cook \& Staden 1982; Nichols 1976), there is no report regarding the overall dry weight of cut carnations. An increased stem length was associated with extended longevity and more dry mass of carnation flower heads (Cook \& Staden 1982). It has been demonstrated that supplied extra sucrose is rapidly inverted and metabolized in the petals causing higher vase life in cut carnation flowers (Nichols $\&$ Ho 1975). The receptacle and stem tissues are, nonetheless, potential carbohydrate sources and probably contribute to the increase in dry matter of the ovary (Nichols 1976). In our experiment, the lowest dry weight content in some experimental treatments coincided with the longest vase life (Table 1), and we assume that the increased total translocation of sugars from reserve tissues to petals was the main cause for decreased dry weight and vase life prolongation. Consequently, an increase in metabolism rate might cause improved retaining of the membrane integrity and consequently lower leakiness of membranes on the $7^{\text {th }}$ day of experiment as indexed by lower EC values.

\section{Chlorophyll content}

Chlorophyll a content was affected significantly by interactions between ethanol, malic acid and succinic acid that make it hard for interpretation of the direct effects of each of these factors (Table 1). Succinic acid at $1 \mathrm{mM}$ increased the chlorophyll a content significantly only at the presence of malic acid due to a synergistic effect. When malic acid was missing, succinic acid reduced the chlorophyll a content (Fig. 2). A near double chlorophyll a content was observed in Succinic acid $1 \mathrm{mM}+$ Malic acid $_{1}$ $\mathrm{mM}+$ Ethanol ${ }_{0 \%}\left(\mathrm{~S}_{1} \mathrm{M}_{1} \mathrm{E}_{0 \%}\right)$ and $\mathrm{S}_{1} \mathrm{M}_{2} \mathrm{E}_{2} \%$, when compared to control $\left(6.8 \mathrm{mg} \cdot \mathrm{g}^{-1}\right)$.

Any noticeable effect on chlorophyll $b$ was not observed. Total chlorophyll followed a relatively similar trend to chlorophyll a in which $\mathrm{S}_{1} \mathrm{M}_{1} \mathrm{E}_{0 \%}$ and $\mathrm{S}_{0} \mathrm{M}_{0} \mathrm{E}_{2 \%}$ (with 18.9 and $14.8 \mathrm{mg} \cdot \mathrm{g}^{-1}$ respectively) had significantly higher total chlorophyll than control $\left(10.4 \mathrm{mg} \cdot \mathrm{g}^{-1}\right)$. The $\alpha$-ketoglutarate is the substrate 
exported from Krebs cycle to produce glutamate and the subsequent conversion of glutamate to the delta-aminolevulinic acid (ALA) as the chlorophyll precursor is a key step in biosynthesis of chlorophyll in higher plants (Sarangthem et al. 2011). We can raise the possibility that increase of malic acid and succinic acid caused an increase in export of their precursor, $\alpha$-ketoglutarate from Krebs cycle. A trend of increased chlorophyll a and total content in those with higher EC was suggested by a significant positive correlation $(0.239$ and 0.299 , significant at $\mathrm{p}<0.05$ and $\mathrm{p}<0.01$ respectively).

\section{Uptake of preservative solution}

Ethanol significantly increased the uptake of preservative solution by cut flowers (Table 1). The malic acid did not influence this trait (Fig. 1B). Except one treatment $\left(\mathrm{S}_{2} \mathrm{M}_{2} \mathrm{E}_{4 \%}\right)$, all other treatments containing $4 \%$ ethanol had significantly more water absorbed compared to control treatment (Table 1) This confirms that ethanol enhanced the water uptake as previously reported (Pun et al. 1999). However, it is reported that uptake of solution is not correlated with the vase life and ethylene production in cut carnations (Pun et al. 1999). This is in accordance with our observation, in which not all of the treatments having higher uptake of preservative solution are present in the longest vase life group. This indicates that perhaps other factors are involved in vase life prolongation. This is illustrated in the path analysis; relative solution uptake could help to reduce the fresh weight loss that is a more important factor for prediction of the vase life but the malic acid is nominated to have reduced the fresh weight loss as well (Fig. 3).

\section{Fresh weight loss}

Ethanol, especially in $4 \%$ strongly reduced the fresh weight loss (Table 1), and the effect seems to be caused primarily via increase in relative solution uptake by cut flowers (Fig. 1C). Succinic acid at $2 \mathrm{mM}$ significantly reduced the fresh weigh loss
(Table 1). While malic acid was relatively less effective on uptake of solution, it reduced the fresh weight loss of cut flowers significantly (Table 1). It was previously concluded that malic acid improves the water balance of the cut carnation flowers by control of the bacterial populations combined with reduction in water loss (Kazemi et al. 2010). In this work, our data supported earlier observation suggesting a regulating role of malic acid in water balance of cut flowers. We know that malic acid is an important osmoticum in guard cells that manages stomatal opening (Allaway 1973; Zeiger 1983). Tarczynski and Outlaw (1990) reported that concentration of malate in guard-cells increases several fold during stomatal opening in Vicia faba. Therefore, a direct role for malic acid in control of stomata function could be also possible in our experiment. For sucrose, it has been proposed previously that at least part of its effect on reduction of water loss could be related to its role in closure of stomata (Marousky \& Raulston 1970). Here, we can conclude that malic acid may have reduced the stomatal conductance in some way to yield such a controlling effect on fresh weight loss. A similar effect by $2 \mathrm{mM}$ succinic acid may exist as well. However, further studies are needed to confirm such an effect.

\section{Membrane integrity}

EC is used as the indicator of membrane integrity. Malic acid was the only factor effective on reduction of EC value (Table 1). This indicates its role on keeping the membrane integrity. Those cut carnation flowers with lower EC had lost significantly less fresh weight and had mobilized more carbohydrates for respiration and metabolism as denoted by less dry weight. This result complies with earlier report regarding positive effect of malic acid on membrane integrity of cut carnations (Kazemi et al. 2012). Here we observed a significant synergism effect between malic acid and ethanol in reduction of solute leakage index (Fig. 1D). 
Table 1. Effect of succinic acid, malic acid and ethanol on the characteristics associated with the vase life of 'White Natila' cut carnation flowers (mean comparison and factor significance)

\begin{tabular}{|c|c|c|c|c|c|c|c|c|c|c|c|}
\hline 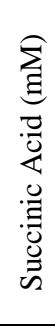 & 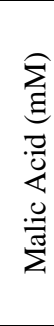 & 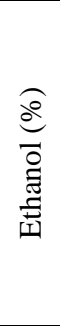 & $\begin{array}{l}\vec{E} \\
\frac{\overrightarrow{0}}{00} \\
\vec{D} \\
3 \\
\vec{D} \\
\overrightarrow{0}\end{array}$ & 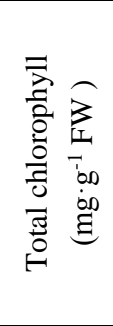 & 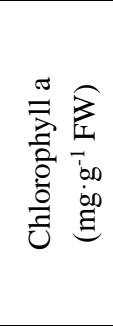 & 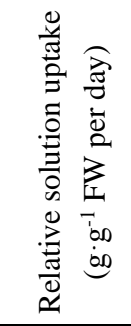 & 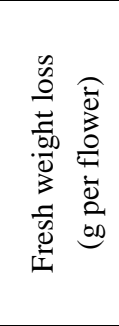 & 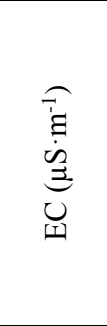 & 空 & 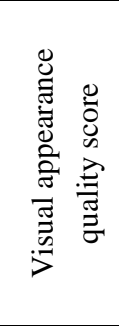 & 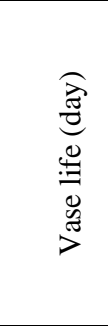 \\
\hline \multirow{9}{*}{0} & \multirow{3}{*}{0} & 0 & $14^{\mathrm{d}}$ & $10.4^{\mathrm{c}-\mathrm{g}}$ & $6.8 \mathrm{def}$ & $0.080^{\mathrm{hi}}$ & $28.3^{j}$ & 623 ghi & $0.118^{\mathrm{m}}$ & $1.7^{\mathrm{b}-\mathrm{f}}$ & $8.9^{b-g}$ \\
\hline & & 2 & $11.7^{\mathrm{c}}$ & $14.8^{\mathrm{b}}$ & $9.8 \mathrm{bc}$ & $0.091^{\mathrm{c}-\mathrm{i}}$ & $24.3^{\mathrm{ij}}$ & $540^{\mathrm{e}-\mathrm{i}}$ & $0.078^{\mathrm{d}-\mathrm{g}}$ & $2.1^{\mathrm{a}-\mathrm{f}}$ & $8.2^{\mathrm{d}-\mathrm{i}}$ \\
\hline & & 4 & $9.2^{\mathrm{b}}$ & $9.9^{\mathrm{c}-\mathrm{g}}$ & $6.6^{\mathrm{def}}$ & $0.118^{a}$ & $17 . \mathrm{gh}^{\mathrm{gh}}$ & $704^{\mathrm{ij}}$ & $0.086^{f-i}$ & $3^{\mathrm{a}-\mathrm{e}}$ & $10^{\mathrm{a}-\mathrm{d}}$ \\
\hline & \multirow{4}{*}{1} & 0 & $12.3^{\mathrm{cd}}$ & 9 efg & $5.8^{\mathrm{f}}$ & $0.090^{\mathrm{e}-\mathrm{i}}$ & $15.4^{\text {e-h }}$ & $634^{g-i}$ & $0.074^{b-f}$ & $3.2^{a b c}$ & $10.1^{\mathrm{abc}}$ \\
\hline & & 2 & $9.6^{b}$ & $9.4^{\mathrm{d}-\mathrm{g}}$ & $6.1^{\mathrm{f}}$ & $0.099^{b-f}$ & $9.4^{\mathrm{a}-\mathrm{f}}$ & $243^{\mathrm{ab}}$ & $0.073^{\text {b-f }}$ & $2.9^{\mathrm{a}-\mathrm{f}}$ & $8.9^{b-g}$ \\
\hline & & 4 & $7.6^{\mathrm{ab}}$ & $8.5^{\text {efg }}$ & $5.6^{\mathrm{f}}$ & $0.108^{a-d}$ & $3^{a b}$ & $404^{a-f}$ & $0.06^{\mathrm{bc}}$ & $3.7^{\mathrm{a}}$ & $11.1^{\mathrm{a}}$ \\
\hline & & 0 & $8.5^{\mathrm{ab}}$ & $9.4^{\mathrm{d}-\mathrm{g}}$ & $6.1^{\mathrm{f}}$ & $0.090^{e-i}$ & $7.2^{\mathrm{a}-\mathrm{d}}$ & $350^{\mathrm{a}-\mathrm{e}}$ & $0.081^{\mathrm{e}-\mathrm{h}}$ & $2.4^{\mathrm{a}-\mathrm{f}}$ & $8.3^{\mathrm{c}-\mathrm{h}}$ \\
\hline & \multirow[t]{2}{*}{2} & 2 & $8.1^{\mathrm{ab}}$ & $11.2^{\mathrm{b}-\mathrm{f}}$ & $7.4 \mathrm{def}$ & $0.105^{\text {a-e }}$ & $2.2^{\mathrm{a}}$ & $492^{\text {e-h }}$ & $0.086^{\mathrm{f}-\mathrm{i}}$ & $3.2^{\mathrm{ab}}$ & $10.1^{\mathrm{abc}}$ \\
\hline & & 4 & 8.6.6 & $10.7^{\mathrm{c}-\mathrm{g}}$ & 7.1 def & $0.118^{\text {a }}$ & $7.1^{\mathrm{a}-\mathrm{d}}$ & $263^{\mathrm{ab}}$ & $0.075^{c-g}$ & $2.6^{a-f}$ & $9.6^{\mathrm{a}-\mathrm{e}}$ \\
\hline \multirow{9}{*}{1} & \multirow{3}{*}{0} & 0 & $8.4^{\mathrm{ab}}$ & $9.9^{\mathrm{d}-\mathrm{g}}$ & $6.8 \mathrm{def}$ & $0.080^{\mathrm{hi}}$ & $13.1^{\mathrm{d}-\mathrm{g}}$ & $355^{\mathrm{a}-\mathrm{f}}$ & $0.095^{\mathrm{h}-\mathrm{j}}$ & $1.4^{\mathrm{c}-\mathrm{f}}$ & $7.9^{\mathrm{e}-\mathrm{i}}$ \\
\hline & & 2 & $7.9^{\mathrm{ab}}$ & $8.8^{\text {efg }}$ & $5.8^{\mathrm{f}}$ & $0.093^{b-i}$ & $16.4^{\mathrm{fgh}}$ & $406^{b-f}$ & $0.098^{\mathrm{i}-\mathrm{k}}$ & $1.1^{\mathrm{f}}$ & $6.7^{\mathrm{hi}}$ \\
\hline & & 4 & $8^{a b}$ & $7^{\mathrm{g}}$ & $5.7^{\mathrm{f}}$ & $0.110^{a b}$ & $7.9^{\mathrm{a}-\mathrm{e}}$ & $467^{\mathrm{d}-\mathrm{g}}$ & $0.064^{\mathrm{b}-\mathrm{d}}$ & $2.5^{\mathrm{a}-\mathrm{f}}$ & $6.8^{\mathrm{hi}}$ \\
\hline & \multirow{4}{*}{1} & 0 & $11.6^{\mathrm{c}}$ & $18.9^{\mathrm{a}}$ & $12.5^{\mathrm{a}}$ & $0.079^{\mathrm{i}}$ & $20.9 \mathrm{hi}$ & $760^{j}$ & $0.102^{\mathrm{jk}}$ & $1.4^{\mathrm{b}-\mathrm{f}}$ & $7.5^{-i}$ \\
\hline & & 2 & $9.4^{\mathrm{b}}$ & $9.2 \mathrm{efg}$ & $6^{\mathrm{f}}$ & $0.090^{\mathrm{e}-\mathrm{i}}$ & $17.7 \mathrm{ghi}$ & $516^{\mathrm{e}-\mathrm{h}}$ & $0.111^{\mathrm{k}-\mathrm{m}}$ & $1.2^{\mathrm{ef}}$ & $6.4^{\mathrm{i}}$ \\
\hline & & 4 & $7.9^{\mathrm{ab}}$ & $13.2 \mathrm{bcd}$ & $8.7^{\text {cde }}$ & $0.104^{\text {a-e }}$ & $8.2^{\mathrm{a}-\mathrm{e}}$ & $546^{\mathrm{f}-\mathrm{i}}$ & $0.040^{\mathrm{a}}$ & $1.9^{\mathrm{b}-\mathrm{f}}$ & $8.5^{\mathrm{c}-\mathrm{h}}$ \\
\hline & & 0 & $8.5^{\mathrm{ab}}$ & $13.7 \mathrm{bc}$ & 9 bcd & $0.085^{\mathrm{f}-\mathrm{i}}$ & $16.4^{\text {fgh }}$ & $468^{\mathrm{d}-\mathrm{g}}$ & $0.111^{\mathrm{k}-\mathrm{m}}$ & $1.1^{\mathrm{f}}$ & $7.2 \mathrm{ghi}$ \\
\hline & \multirow[t]{2}{*}{2} & 2 & $8.6^{\mathrm{ab}}$ & $11.8^{\mathrm{b}-\mathrm{f}}$ & $11^{\mathrm{ab}}$ & $0.097^{\mathrm{b}-\mathrm{i}}$ & $13.2^{\mathrm{d}-\mathrm{g}}$ & $277^{\mathrm{a}-\mathrm{d}}$ & $0.067^{\mathrm{b}-\mathrm{e}}$ & $2.4^{\mathrm{a}-\mathrm{f}}$ & $8.8^{\mathrm{c}-\mathrm{g}}$ \\
\hline & & 4 & $9.5^{\mathrm{b}}$ & $10.2^{\mathrm{c}-\mathrm{g}}$ & $6.8 \mathrm{def}$ & 0.109 abc & $3.7 \mathrm{ab}$ & $270^{a b c}$ & $0.076^{\mathrm{c}-\mathrm{g}}$ & $3.2^{\mathrm{abc}}$ & 10.7 ab \\
\hline \multirow{9}{*}{2} & \multirow{3}{*}{0} & 0 & $7.9^{\mathrm{ab}}$ & $10.9^{\mathrm{c}-\mathrm{f}}$ & $7.5^{\mathrm{c}-\mathrm{f}}$ & $0.080^{\text {ghi }}$ & $11.8^{\mathrm{c}-\mathrm{g}}$ & $463^{a-g}$ & $0.116^{\mathrm{lm}}$ & $1.3^{\mathrm{ef}}$ & $7.9^{\mathrm{e}-\mathrm{i}}$ \\
\hline & & 2 & $8^{\mathrm{ab}}$ & $12.3^{\mathrm{b}-\mathrm{e}}$ & $8^{\mathrm{c}-\mathrm{f}}$ & $0.096^{\mathrm{b}-\mathrm{i}}$ & $12.8^{\mathrm{d}-\mathrm{g}}$ & $676^{\text {hij }}$ & $0.078^{\mathrm{d}-\mathrm{g}}$ & $1.1^{\mathrm{f}}$ & $8.5^{\mathrm{c}-\mathrm{h}}$ \\
\hline & & 4 & $8.5^{\mathrm{ab}}$ & $9.1 \mathrm{efg}$ & $6^{\mathrm{f}}$ & $0.104^{\mathrm{a}-\mathrm{e}}$ & $5.7^{\mathrm{a}-\mathrm{d}}$ & $456^{\mathrm{c}-\mathrm{g}}$ & $0.082^{\mathrm{e}-\mathrm{h}}$ & $3^{\mathrm{a}-\mathrm{e}}$ & $9.5^{\mathrm{a}-\mathrm{e}}$ \\
\hline & \multirow{4}{*}{1} & 0 & $8.2^{\mathrm{ab}}$ & $10.1^{\mathrm{c}-\mathrm{g}}$ & 6.8 def & $0.094^{b-i}$ & $5.9^{\mathrm{a}-\mathrm{d}}$ & 489 efg & $0.082^{\text {e-h }}$ & $1.1^{\mathrm{f}}$ & $7.6^{\mathrm{f}-\mathrm{i}}$ \\
\hline & & 2 & $9.5^{\mathrm{b}}$ & $9.2 \mathrm{efg}$ & $6.1^{\mathrm{f}}$ & $0.096^{\mathrm{b}-\mathrm{i}}$ & $10.8^{\mathrm{b}-\mathrm{g}}$ & $399^{b-f}$ & $0.063^{\mathrm{b}-\mathrm{d}}$ & $2.5^{\mathrm{a}-\mathrm{f}}$ & $10.1^{\mathrm{abc}}$ \\
\hline & & 4 & $7.5^{\mathrm{ab}}$ & $8.3^{\mathrm{fg}}$ & $5.5^{\mathrm{f}}$ & $0.098^{\mathrm{b}-\mathrm{g}}$ & $3.8^{\mathrm{ab}}$ & $406^{b-f}$ & $0.084^{\mathrm{f}-\mathrm{i}}$ & $2^{a-f}$ & $8.8^{c-g}$ \\
\hline & & 0 & $8.5^{\mathrm{ab}}$ & $8.4^{\text {efg }}$ & $5.6^{\mathrm{f}}$ & $0.087^{\mathrm{d}-\mathrm{i}}$ & $6.6^{\mathrm{a}-\mathrm{b}}$ & $211^{\mathrm{a}}$ & $0.091^{\mathrm{g}-\mathrm{j}}$ & $1.3^{\mathrm{def}}$ & $9.1^{\mathrm{b}-\mathrm{f}}$ \\
\hline & \multirow[t]{2}{*}{2} & 2 & $6.8^{\mathrm{a}}$ & 8.8 efg & $5.8^{\mathrm{f}}$ & $0.102^{a-f}$ & $2.4^{\mathrm{a}}$ & $354^{\mathrm{a}-\mathrm{f}}$ & $0.063^{\mathrm{b}-\mathrm{d}}$ & $3.1^{\mathrm{a}-\mathrm{d}}$ & $8.9^{b-g}$ \\
\hline & & 4 & $6.7^{\mathrm{a}}$ & $8.9^{\mathrm{efg}}$ & $6.3^{\text {ef }}$ & $0.097^{\text {b-h }}$ & $4.3^{\mathrm{abc}}$ & $468^{\mathrm{d}-\mathrm{g}}$ & $0.059^{\mathrm{b}}$ & $2.6^{\mathrm{a}-\mathrm{f}}$ & $8.8^{\mathrm{c}-\mathrm{g}}$ \\
\hline \multicolumn{12}{|c|}{ Probability of $\mathbf{F}$ statistic for tested effects of factors and their interaction } \\
\hline \multicolumn{3}{|c|}{ Succinic Acid } & 0.000 & 0.005 & 0.000 & 0.054 & 0.000 & 0.405 & 0.063 & 0.001 & 0.000 \\
\hline \multicolumn{3}{|c|}{ Malic Acid } & 0.000 & 0.806 & 0.761 & 0.173 & 0.000 & 0.000 & 0.000 & 0.133 & 0.014 \\
\hline \multicolumn{3}{|c|}{ Ethanol } & 0.000 & 0.011 & 0.015 & 0.000 & 0.000 & 0.151 & 0.000 & 0.000 & 0.001 \\
\hline \multicolumn{12}{|c|}{ Succinic Acid } \\
\hline \multicolumn{3}{|c|}{ * Malic Acid } & 0.000 & 0.000 & 0.000 & 0.618 & 0.000 & 0.000 & 0.000 & 0.227 & 0.012 \\
\hline \multicolumn{3}{|c|}{ Succinic Acid } & & & & & & & & & \\
\hline \multicolumn{3}{|c|}{$*$ Ethanol } & 0.018 & 0.000 & 0.004 & 0.048 & 0.029 & 0.011 & 0.000 & 0.553 & 0.139 \\
\hline \multicolumn{12}{|c|}{ Malic Acid * } \\
\hline \multicolumn{3}{|c|}{ Ethanol } & 0.007 & 0.003 & 0.001 & 0.144 & 0.076 & 0.000 & 0.001 & 0.066 & 0.181 \\
\hline \multicolumn{3}{|c|}{$\mathrm{SA} * \mathrm{MA} * \mathrm{Et}$} & 0.004 & 0.371 & 0.002 & 0.965 & 0.125 & 0.001 & 0.000 & 0.662 & 0.001 \\
\hline
\end{tabular}

Numbers represent average of three replications

Averages that have the same letters in each column are not significantly different at 5\% level, according to Duncan test 

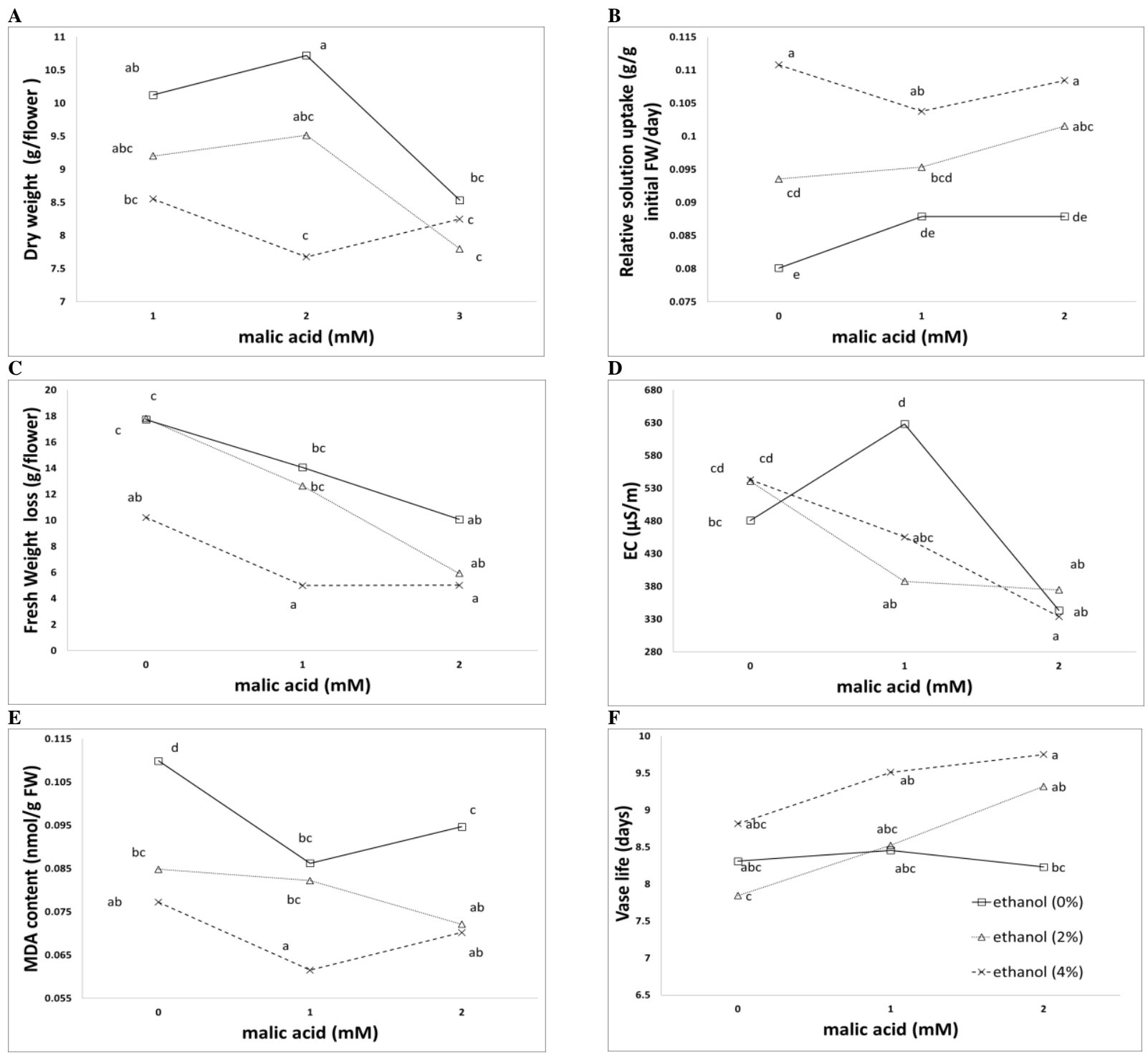

Fig. 1. The interaction effect between malic acid and ethanol on dry weight (A), relative solution uptake (B), fresh weight loss (C), electrical conductivity (D), malondialdehyde content (E) and vase life (Based on the marginal means across different succinic acid levels)

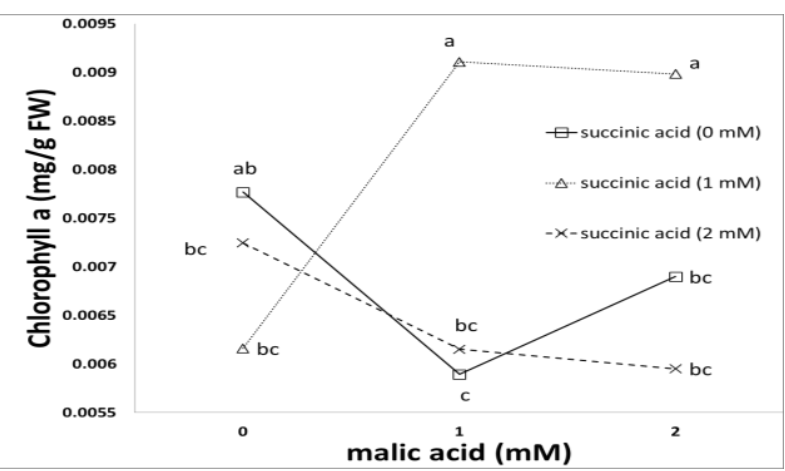

Fig. 2. The interaction effect between succinic acid and malic acid on chlorophyll a content. A synergism between $1 \mathrm{mM}$ succinic acid and malic acid is notable (based on the marginal means across different ethanol levels)

\section{Malondialdehyde content}

MDA is an estimator for lipid peroxidation and so is an indicator of oxidative stress level in the tissue (Hodges et al. 1999). Both malic acid and ethanol reduced the MDA content significantly (Table 1, Fig. 1E). Similarly to EC, the reduction in MDA coincided with limited loss in fresh weight and more use of internal carbohydrate as denoted by less dry weight. Comparing the EC value, which showed a good correlation with chlorophyll content, MDA content, had acted as a good predictor of the appearance quality instead, as denoted by a significant negative correlation $(-0.223, \mathrm{p}<0.05)$. 
Our results agree with previous results on the effect of malic acid on reduction of MDA content in carnations (Kazemi et al. 2012).

\section{Visual appearance quality}

While visual appearance quality, which was measured on 7th day, is correlated significantly with the vase life $(0.591, \mathrm{p}<0.01)$, but it could be considered as a more practical measure of consumer acceptability or marketability of cut flowers. Succinic acid significantly decreased the visual appearance quality while $4 \%$ ethanol increased it. The greatest visual quality scores were associated with shoots that displayed enhanced water balance. Visual appearance quality showed a significant positive correlation with the relative solution uptake $(0.444$, $\mathrm{p}<0.01$ ), while having a significant negative correlation with the fresh weight loss $(-0.360$, $\mathrm{p}<0.01)$. The treatment with highest quality score $\left(\mathrm{S}_{0} \mathrm{M}_{1} \mathrm{E}_{4 \%}\right)$ had the longest vase life, as well. Presence of a significant positive correlation between vase life and visual appearance quality (0.591, $\mathrm{p}<0.01)$ makes it possible to consider it as a proper indicator of vase life especially in conditions when the time course of experiment is limited. The observation of significant negative correlation between MDA content and the visual appearance quality $(-0.223$, $\mathrm{p}<0.05)$ and lack of such a correlation with length of vase life values suggests that the visual appearance quality could be considered a more dependable representative of the physiological aging parameters like MDA accumulation. The pattern of effect resulted from path analysis suggests that while visual appearance quality can predict the vase life in part but it is not necessarily affected by the same factors that control the vase life (Fig. 3). This was observed previously by Jamshidi et al. (2012). We suggest that evaluation of visual appearance quality could be regarded as a complementary or even substitute to vase life. In fact, vase life alone could not be regarded as a good index of how marketable the flowers are, and it seems that the scoring based on visual quality could give a better prediction for market quality of cut flowers or how they will appear from consumer's viewpoint.

\section{Vase life}

Factorial analysis revealed that ethanol increased the length of vase life from 8.3 at 0 to 9.4 days at $4 \%$ concentration but differences are not significant (Fig. 1F). Similarly, malic acid increased mean vase life from 8.3 at 0 level to 9.1 days at $2 \mathrm{mM}$ level while succinic acid decreased the mean vase life from 9.5 at 0 level to 7.9 days at $2 \mathrm{mM}$ level (Table 1). The longest vase life was recorded at $\mathrm{S}_{0} \mathrm{M}_{1} \mathrm{E}_{4 \%}$ (11.1 comparing to 8.9 days in control), as the only treatment causing statistically significant increase in vase life comparing the control treatment. The mechanism of action for ethanol was reported earlier as limiting ethylene production in ovaries, which create a strong sink in absence of ethanol (Podd et al. 2002). Possibly, ethanol increased the vase life in our experiment by the same mechanism. The positive effect of malic acid was previously reported (Jamshidi et al. 2012; Kazemi et al. 2010, 2012; Sabzi et al. 2012). Since we did not observe similar effect to malic acid by application of succinic acid, we can conclude that the conversion of applied succinic acid to malic acid in Krebs cycle did not take place in a noticeable extent to cause any response in cut carnation flowers. There remains other means for malic acid to effect on the vase life. Part of malic acid effect could be attributed to its ability to reduce of ACC oxidase activity as reported before, which could affect some ageing related pathways like increased membrane integrity that is confirmed in our study as lower EC and MDA content (Kazemi et al. 2010, 2012). Malic acid could have had a limiting effect on bacterial growth in vase solution as reported earlier (Jamshidi et al. 2012; Kazemi et al. 2010). From our results, we can add that malic acid could increase the vase life by limiting the fresh weight loss. 


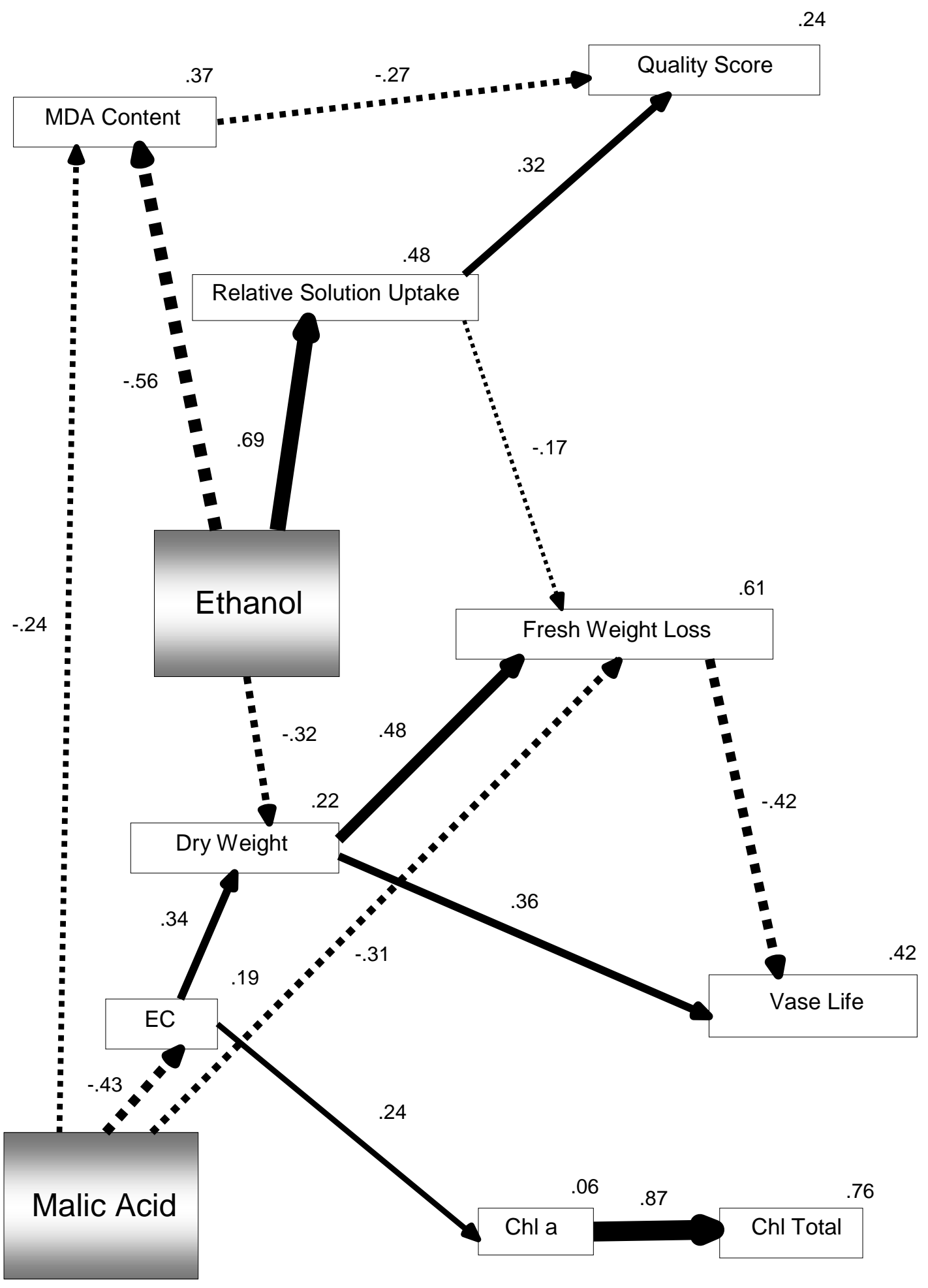

Fig. 3 The Path Analysis of experimental data. Dashed lines indicate negative coefficients, and the width of the arrow indicates the strength of the effect. The lines represent significant effect and the numbers on arrows are Standardized regression coefficients (when factor goes up or down by 1 standard deviation, the variable goes up or down by the multiply of mentioned number in its standard deviation). The numbers on the upper corner of each variable are determination coefficients $\left(\mathrm{R}^{2}\right)$. For example, it is estimated that the predictors of the vase life explain 42 percent of its variance). Succinic acid effects were removed due to less importance to make the diagram simpler. Variation due to error is not included for simplicity 


\section{CONCLUSION}

The path analysis helps us to visualize an overall view to understand how each factor had affected on the outcome of the experiment. We can conclude that ethanol by: 1 . increase of relative solution uptake; 2 . reduction of oxidative stress as figured here by lower MDA content and 3. increase of metabolism level and metabolites mobility as observed by lower dry weight, had helped the cut carnation flowers to last longer. Malic acid decreased both MDA content and $\mathrm{EC}$ value together, so it has retarded the oxidative stress to cut flowers with additional effect on plasma membrane. Like ethanol, it caused decrease in dry weight, interpreted as increasing of carbohydrate reservoir mobility toward sink organs leading to a longer flower longevity and retarded senescence. Malic acid could help retaining a better water potential and balance in cut flowers leading to decreased fresh weight loss. While further work on mechanism of action of malic acid seems essential, the observed significant positive synergism with ethanol makes it advisable to combine them in preservative solutions to extend the vase life of cut spray carnation.

\section{REFERENCES}

Allaway W. 1973. Accumulation of malate in guard cells of Vicia faba during stomatal opening. Planta 110: 63-70. DOI: $10.1007 /$ BF00386923.

Arnon D.I. 1949. Copper enzymes in isolated chloroplasts. Polyphenoloxidase in Beta vulgaris. Plant Physiol. 24: 1. DOI: 10.1104/pp.24.1.1.

Bleecker A.B., Kende H. 2000. Ethylene: A gaseous signal molecule in plants. Annual Review of Cell and Developmental Biology. 16: 1-18. DOI: 10.1146/annurev.cellbio.16.1.1.

Brickell C. 2010. RHS encyclopedia of plants and flowers. Dorling Kindersley Ltd.

Cook E., Staden J. 1982. Senescence of cut carnation flowers: Ovary development and $\mathrm{CO}_{2}$ fixation. Plant Growth Regul. 1: 221-232. DOI: 10.1007/BF00024716.

Darandeh N., Hadavi E. 2012. Effect of pre-harvest foliar application of citric acid and malic acid on chlorophyll content and post-harvest vase life of Lilium cv. Brunello. Frontiers in Crop Science and Horticulture 2. DOI: 10.3389/fpls.2011.00106.
Halevy A.H., Mayak S. 1981. Senescence and postharvest physiology of cut flowers. Part 2. Hort. Rev 3: 59-143. DOI: $10.1002 / 9781118060766 . c h 3$.

Heath R.L., Packer L. 1968. Photoperoxidation in isolated chloroplasts: I. Kinetics and stoichiometry of fatty acid peroxidation. Arch. Biochem. Biophys. 125: 189-198. DOI: 10.1016/0003-9861(68)90654-1.

Heins R., Blakely N. 1980. Influence of ethanol on ethylene biosynthesis and flower senescence of cut carnation. Sci. Hortic. 13: 361-369. DOI:10.1016/0304-4238(80)90094-1.

Hodges D.M., DeLong J.M., Forney C.F., Prange R.K. 1999. Improving the thiobarbituric acid-reactivesubstances assay for estimating lipid peroxidation in plant tissues containing anthocyanin and other interfering compounds. Planta 207: 604-611. DOI: $10.1007 / \mathrm{s} 004250050524$.

Jamshidi M., Hadavi E., Naderi R. 2012. Effects of salicylic acid and malic acid on vase life and bacterial and yeast populations of preservative solution in cut gerbera flowers. International Journal of AgriScience 2(8): 671-674.

Kazemi M., Hadavi E., Hekmati J. 2010. The effect of malic acid on the bacteria populations of cut flowers of carnations vase solution. World App. Sci. J. 10: 737-740.

Kazemi M., Hadavi E., Hekmati J. 2012. Effect of salicylic acid, malic acid, citric acid and sucrose on antioxidant activity, membrane stability and ACC-oxidase activity in relation to vase life of carnation cut flowers. J. Plant Technol. 7: 78-84. DOI: 10.3923/jps.2012.78.84.

Kelly M.O., Saltveit Jr M.E. 1988. Effect of endogenously synthesized and exogenously applied ethanol on tomato fruit ripening. Plant Physiol. 88: 143-147. DOI: 10.1104/pp.88.1.143.

Kolupaev Y.E., Yastreb T., Shvidenko N., Karpets Y.V. 2012. Induction of heat resistance of wheat coleoptiles by salicylic and succinic acids: Connection of the effect with the generation and neutralization of reactive oxygen species. Applied Biochemistry and Microbiology 48: 500-505. DOI: $10.1134 / \mathrm{S} 0003683812050055$.

Kosugi Y., Oyamada N., Satoh S., Yoshioka T., Onodera E., Yamada Y. 1997. Inhibition by 1-aminocyclobutane1-carboxylate of the activity of 1-aminocyclopropane1-carboxylate oxidase obtained from senescing petals of carnation (Dianthus caryophyllus L.) flowers. Plant Cell Physiol. 38: 312-318. DOI: 10.1093/oxfordjournals.pcp.a029168. 
Marousky F., Raulston J. 1970. Interaction of flower preservative components and light on fresh weight and longevity of snapdragon cut flowers. Proceedings of the 83rd Annual Meeting of the Florida State Horticultural Society. Miami Beach, USA, pp. 445 448.

Mayers A., Newman J., Reid M., Dodge L. 1997. New ethylene inhibitor could extend flower life. Perishables Handling Quarterly 92: 9-11.

Nichols R. 1968. The response of carnations (Dianthus caryophyllus) to ethylene. J. Hort. Sci. 43: 335-349.

Nichols R. 1976. Cell enlargement and sugar accumulation in the gynaecium of the glasshouse carnation (Dianthus caryophyllus L.) induced by ethylene. Planta 130: 47-52. DOI: 10.1007/BF00390843.

Nichols R., Ho L. 1975. Effects of ethylene and sucrose on translocation of dry matter and $14 \mathrm{c}$-sucrose in the cut flower of the glasshouse carnation (Dianthus caryophyllus) during senescence. Ann. Bot. 39: 287-296.

Podd L., Hills P., Van Staden J. 2002. Physiological response and extension of vase life of cut carnation flowers treated with ethanol and acetaldehyde. I. Protein content and enzyme activity. Plant Growth Regul. 38: 107-117. DOI: 10.1023/A:1021267712167.

Podd L., Van Staden J. 1998. The role of ethanol and acetaldehyde in flower senescence and fruit ripening - a review. Plant Growth Regul. 26: 183-189. DOI: 10.1023/A:1006131517539.

Podd L., Van Staden J., 1999a. Is acetaldehyde the causal agent in the retardation of carnation flower senescence by ethanol? J. Plant Physiol. 154: 351-354. DOI: 10.1016/S0176-1617(99)80179-5.

Podd L., Van Staden J. 1999b. The use of acetaldehyde to control carnation flower longevity. Plant Growth Regul. 28: 175-178. DOI: 10.1023/A:1006246617729.

Podd L., Van Staden J. 2002. Physiological response and extension of vase life of cut carnation flowers treated with ethanol and acetaldehyde. I. Chlorophyll content and carbohydrate status. Plant Growth Regul. 38: 99-105. DOI: 10.1023/A:1021267712167.

Pun U., Rowarth J., Barnes M., Heyes J. 2001a. The role of ethanol or acetaldehyde in the biosynthesis of ethylene in carnation (Dianthus caryophyllus L.) cv. Yellow candy. Postharvest Biol. Technol. 21: 235-239. DOI: 10.1016/S0925-5214(00)00111-3.
Pun U., Rowarth J., Barnes M., Heyes J., Rowe R., Dawson C. 2001b. The influence of exogenous acetaldehyde solution on the vase life of two carnation (Dianthus caryophyllils L.) cultivars in the absence or presence of exogenous ethylene. Plant Growth Regul. 34: 267-272. DOI: 10.1023/A:1013345908827.

Pun U., Rowe R., Rowarth J., Barnes M., Dawson C., Heyes J. 1999. Influence of ethanol on climacteric senescence in five cultivars of carnation. New Zealand Journal of Crop and Horticultural Science 27: 69-77. DOI: 10.1080/01140671.1999.9514082.

Rao K.J., Shantaram M. 2003. Soil and water pollution due to open landfills. Proceedings of sustainable landfill management workshop, pp. 3-5.

Reid M., Kofranek A.M., Besemer S.T. 1983. Postharvest handling of carnations. Acta Hort. 141: 235 238.

Reid M.S. 2004. Cut flowers and greens. In: Gross K.C., Wang C.Y., Saltveit M. (Eds.), Agriculture Handbook Number 66. The Commercial Storage of Fruits, Vegetables, and Florist and Nursery Stocks. www.ba.ars.usda.gov/hb66/cutFlowers.pdf

Sabzi A., Hadavi E., Hekmati J. 2012. Effect of different levels of malic acid and salicylic acid in preservative solution on the quality and vase life of cut rose flowers cultivars (Utopia). International Journal of AgriScience 2: 403-407.

Saltveit M.E. 1989. Effect of alcohols and their interaction with ethylene on the ripening of epidermal pericarp discs of tomato fruit. Plant Physiol. 90: 167-174. DOI: $10.1104 /$ pp.90.1.167.

Sarangthem J., Jain M., Gadre R. 2011. Inhibition of $\delta$ aminolevulinic acid dehydratase activity by cadmium in excised etiolated maize leaf segments during greening. Plant, Soil and Environment-UZEI 57.

Satler S.O., Thimann K.V. 1980. The influence of aliphatic alcohols on leaf senescence. Plant Physiol. 66: 395399. DOI: 10.1104/pp.66.3.395.

Suzuki Y., Uji T., Terai H. 2004. Inhibition of senescence in broccoli florets with ethanol vapor from alcohol powder. Postharvest Biol. Technol. 31: 177-182. DOI: 10.1016/j.postharvbio.2003.08.002.

Tarczynski M.C., Outlaw W.H. 1990. Partial characterization of guard-cell phospho-enolpyruvate carboxylase: Kinetic datum collection in real time from single-cell activities. Arch. Biochem. Biophys. 280: 153-158. DOI: 10.1016/0003-9861(90)90530C. 
Terék O., Mosonyi I., Jámbor-Benczúr E., Hassan F., Máthé Á. 2009. Effect of different treatments on vase life of carnation 'Gioko'. VI International Postharvest Symposium 877, pp. 1757-1762.

UNComtrade 2011. The united nations commodity trade statistics database (un comtrade), http://comtrade.un.org

Wu M.J., Zacarias L., Saltveit M.E., Reid M.S. 1992. Alcohols and carnation senescence. HortScience 27: 136-138.
Zamani S., Hadavi E., Kazemi M., Hekmati J. 2011. Effect of some chemical treatments on keeping quality and vase life of chrysanthemum cut flowers. World Appl. Sci. J. 12: 1962-1966.

Zeiger E. 1983. The biology of stomatal guard cells. Annual Review of Plant Physiology 34: 441-474. DOI: 10.1146/annurev.pp.34.060183.002301

Zeng C., Liu L., Xu G. 2011. The physiological responses of carnation cut flowers to exogenous nitric oxide. Sci. Hortic. 127: 424-430. DOI: 10.1016/j.scienta.2010.10.024. 